\title{
Remote Sensing Based Analysis of Land Use/Cover Change Impact in the Interface Between Magamba Nature Reserve and Surrounding Villages in Lushoto District, Tanzania
}

\author{
Oforo Didas Kimaro ${ }^{1,}$, , Simon Chidodo \\ ${ }^{1}$ Department of Agriculture, Earth and Environmental Science, Mwenge Catholic University, Moshi, Tanzania \\ ${ }^{2}$ Department of Ecotourism and Nature Conservation, Sebastian Kolowa Memorial University, Lushoto-Tanga, Tanzania
}

Email address:

didasoforo@yahoo.com (O. D. Kimaro)

${ }^{*}$ Corresponding author

To cite this article:

Oforo Didas Kimaro, Simon Chidodo. Remote Sensing Based Analysis of Land Use/Cover Change Impact in the Interface Between Magamba Nature Reserve and Surrounding Villages in Lushoto District, Tanzania. American Journal of Environmental Protection. Vol. 10, No. 1, 2021, pp. 1-11. doi: 10.11648/j.ajep.20211001.11

Received: November 11, 2020; Accepted: November 26, 2020; Published: March 3, 2021

\begin{abstract}
Several studies in Tanzania focus on land use/cover change (LULC) at coarse scale and without considering the adjoining (interface) landscapes i.e. landscape link community farming systems and forest/nature reserves. In the Eastern Arc Mountains in particular, LULC change that confront the interface between surrounding community landscape and nature reserves and the associated livelihood are not well understood. A study was conducted in the Usambara Mountains, Tanzania to explore the potential impacts of LULC on the interface between Magamba Nature Reserve (MNR) and the landscape of the surrounding community villages. Remote sensing and GIS techniques were used to quantify and analyse the trend in LULC changes over the past 31 years whereby satellite images of 1984, 1995 and 2015 were used. Household surveys, field observations and focus group discussions to 72 households in 3 villages surrounding the nature reserve were employed to capture data on human activities in the interface. The change detection was done by post classification approach using image interpreter| GIS analysis| matrix tool in QGIS software and processed in an intensity analysis program (Pontius matrix excel sheet). Descriptive statistical analysis (frequency counts and percentages) was used to explain human activities of communities adjacent to the MNR. Qualitative data were analysed using content and structural functional analytical techniques. Over the period (1984-2015) natural forest covering the major part of reserve decreased by $14 \%$. The declining trend for forests in the study area is largely attributed to the increasing agricultural activities, settlements and infrastructure. Results revealed further that natural forest area and wetlands had active intensity of gain over the period 1984-1995 while in the 1995-2015 period had active intensity of loss. The most common human activities related to the spatial and temporal dynamics of LULC change in the MNR interface were firewood collection for household use, collection of medicinal plants, illegal timber harvesting, animal grazing, cutting trees for building poles and charcoal burning. Firewood collection is the most important human activity associated with forest degradation in MNR interface. Collection of medicinal plants from the reserve is associated with forest destructive process in the sense that it involves uprooting plants, root cutting, and tree ring debarking. The study recommends that policy makers as well as nongovernmental organizations should identify and establish potential low cost alternative sources of energy for usage by rural domestic household. Further research to predict and map spatial and temporal LULC dynamics at landscape scale should consider future scenarios on the evolution of forest-rural landscape interfaces and their impact on the provisioning of ecosystem services (ESS).
\end{abstract}

Keywords: Land Use/Cover, Magamba Nature Reserve Interface, Remote Sensing and GIS Techniques, Usambara Mountains, Tanzania 


\section{Introduction}

Global climate and ongoing changes threaten the livelihood of smallholder farmers mainly in developing countries particularly in sub-Saharan Africa (SSA) [13]. Changes in climate, pose the most serious environmental threat to the fight against hunger, malnutrition, disease and poverty in developing countries, mainly through its impact on agricultural productivity [15]. In Tanzania smallholder farmers faces serious challenges in agricultural production due to changes in rainfall and growing season characteristics [27]. For example, a study by [11] indicated that the climate of Arusha District, in Tanzania is changing in terms of both the length of the growing season and number of wet days within the season in a decreasing trend. In this study, it was demonstrated that rains appear to be starting later than they used to in the past while other meteorological variables such as temperature, wind speed and reference evapotranspiration have been showing an increasing trend. The changing climate in this area is attributed to long term changes in land use/cover (over 20 years) exacerbated by expansion of agricultural land and population pressure. Another study conducted in semiarid areas of Iringa region in Tanzania, reported that smallholder farmers perceived climate change in terms of changes in temperature, rainfall, increase in drought condition and increase in malaria and crop pests and diseases [11]. In this study it was observed that change in rainfall and temperature patterns, and occurrence of pests and diseases had significant impact on food security and smallholder farmers' livelihood.

In Tanzania, famine resulting from drought has become increasingly common since the mid-1990s [33, 34], and for large parts of the country, including the Eastern Arc Mountains and central regions, the percentage of "failing seasons" is likely to increase [20,34] indicated that for the periods between 1985-2010 the long term land use/cover changes of Pugu and Kazimzumbwi Forest Reserves in Dar es Salaam and Kisarawe areas in Tanzania have been the major influence of changes observed in rainfall pattern, drought and agriculture production which have impacted negatively on the livelihood of the communities in the area. Similar observations were made in Manyoni District in central Tanzania where changes in land use/cover is attributed to changes of rainfall pattern and length of growing season linked with decreasing agricultural productivity $[18,17]$. Other several studies reported similar results $[14,16,15]$.

Several studies have been done in Tanzania on land use/cover change and climate change impacts, vulnerability, and adaptation strategies. Many of these studies have been done at course scale and without considering the adjoining (interface) landscapes i.e. landscape that link for example community farming systems and forest/nature reserves [37, $38,39]$. It is also noted that most of these studies were done in semi-arid areas of Tanzania. In the Eastern Arc Mountains in particular, land use/cover change that confront the interface between surrounding community landscape and nature reserves are interesting hotspot for studies on the potential impact of land use/cover change, changes on climate and communities livelihood. However, such studies and particularly in the Eastern Arc Mountains where unique interfaces between forest reserve and farming community are common have not been done adequately.

In many of the existing pilot forest management projects, land use data have been determined from simple logical argument based on assuming continuation of past trends (Sandra et al., 2003). Also studies on forest degradation have not been linked to the anthropogenic activities at the scale of landscape. For instance, studies conducted at the slopes of Mount Kilimanjaro, Tanzania including Montane forest belt revealed that cultivation and timber harvesting are the main drivers of forest degradation [40, 11]. Also addresses a similar study on the contribution of shifting cultivation towards forest degradation in Tanzania. In this study it was reported that farming practices including slash and burn were among other factors influenced the forest cover changes in the interface. Similar interfaces can be observed in the Usambara Mountains in particular the Magamba Nature Reserve (MNR) and the surrounding farming communities' landscape where many challenges between livelihood and conservation are experienced. Other studies that have been conducted on forest resources in the Eastern Arc Mountain forests and miombo woodlands in Tanzania largely have focussed on biological diversity [3], carbon stocks [35, 36] and soil organic carbon stocks (Kirsten et al., 2014) However, the land use/cover dynamics and the underlying drivers that confront the interface between forest reserves and village landscapes are not well understood [6]. These types of landscapes are frequently occurring across the African continent and anthropogenic influences make them highly dynamic. So far literature lacks a clear approach and typology for characterising forest reserves-village interface landscapes [22]. Therefore, interface between Magamba Nature Reserve (MNR) and the surrounding villages was selected in this study for a case to investigate the impacts of land use/cover change using remote sensing techniques.

The history of Magamba area in the Usambara Mountains, Tanzania date back from the beginning of the $20^{\text {th }}$ century when the German government claimed all unused or unoccupied lands to be suitable for forestry uses. By 1909 there were $15,600 \mathrm{~km}^{2}$ reserved land which became the Magamba Forest Reserve [42]. In 1964, just after the independence, large areas of the reserve have been cleared (about 14, 175 ha) for a new settlement and cultivation. Currently, Magamba Nature Reserve (MNR) has an area of about 9,284 ha [41]. Like many other forest reserves in Tanzania, Magamba Nature Reserve is surrounded by land uses that compete with the conservation purpose of the reserve due to ongoing land use/cover changes and probably the effect of climate change [41]. This calls for a need to quantify the impacts of land use/cover change particularly on climate and peoples livelihood at a landscape scale taking into consideration the confronting interface between communities and the nature reserve. Hence, a study was 
carried out in the Usambara Mountains, Tanzania to explore the potential impacts of land use/cover change on the interface between Magamba Nature Reserve (MNR) and the landscape of the surrounding community villages. The specific objectives were to i) determine the historical land use/cover change using remote sensing and GIS techniques over a period of 31 years (1984 and 2015), ii) to analyse effect of human activities on land use/cover change in the Magamba Nature Reserve interface.

\section{Materials and Methods}

\subsection{Description of Study Area}

The study was conducted in the interface between
Magamba Nature Reserve and three hamlets sub-villages namely Bondeni, Cost, and Mshelemule with an area of about 553 ha, 221 ha and 553 ha respectively. The study sites were selected due to the fact that they reflect land use/cover dynamics associated with forest degradation, changes in micro-climate trends and alteration in crops productivity. The area is also a hot spot for conservation, restoration and sustainable use of natural carbon sinks (i.e. ecological restoration of degraded lands and forests significant to conservation of biodiversity). The study area is located between Universal Transverse Mercator (UTM) coordinates 320000 and $323000 \mathrm{E}$ and 9472000 and $9478000 \mathrm{~N}$, UTM Zone $37 \mathrm{M}$ (Figure 1).

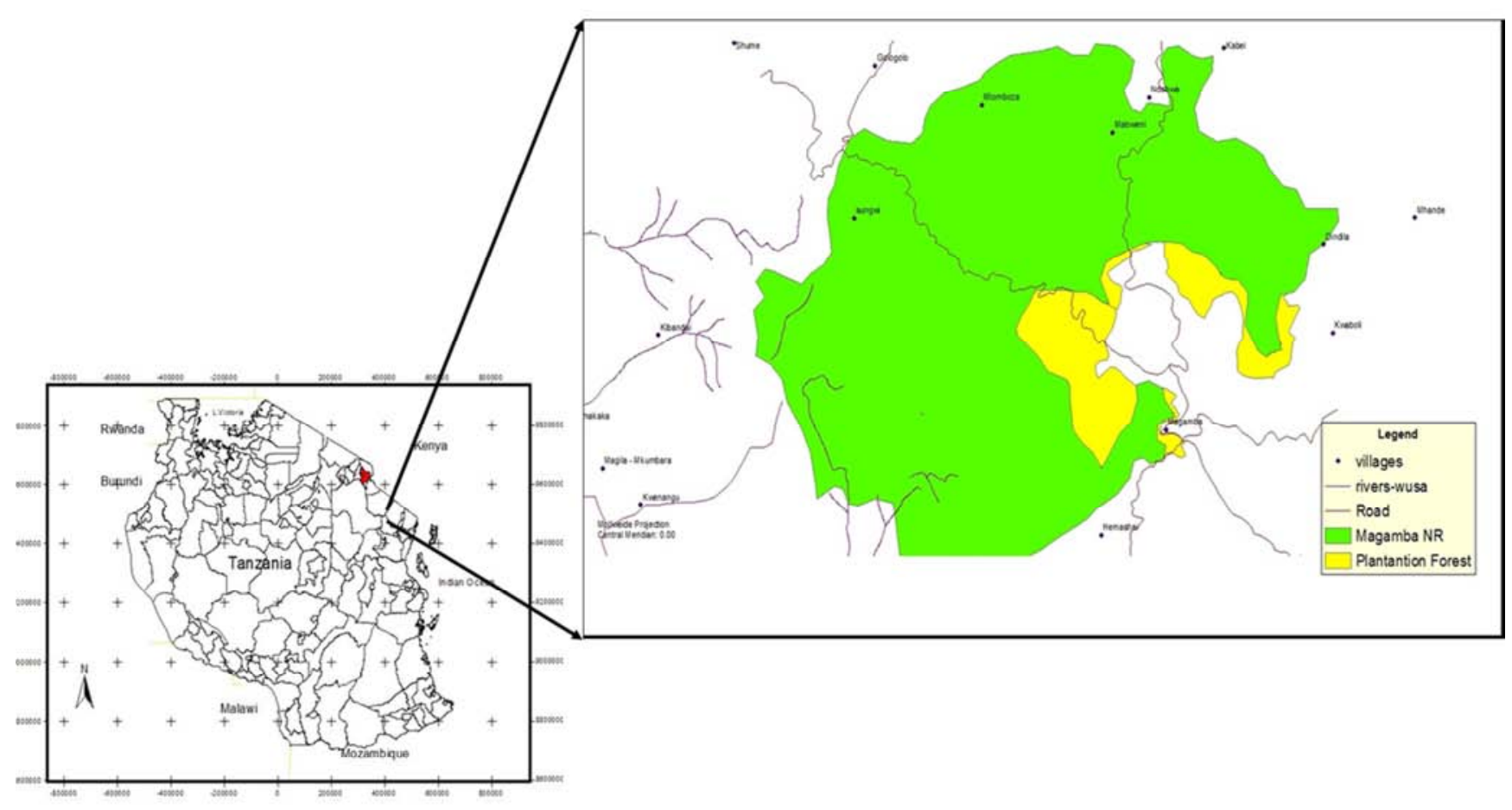

Figure 1. Location map of the Study Area.

\subsubsection{Climate}

The climatic condition of the area is characterized by cool weather throughout the year. The area experiences a sub humid tropical climate with a bi modal rainfall pattern characterized by two rainfall season in a year. The dry season is separated by the long rains which starts from March to May/June (masika) and short rains between October and December (Vuli) [45]. The mean annual rainfall and temperature vary with altitude. The mean annual rainfall is $600-2000 \mathrm{~mm}$ per annum. The mean annual temperature varies with altitude ranging from 17 to $18^{\circ} \mathrm{C}$ on the plateau at 1500 - 1800 m a.s.l. [43].

\subsubsection{Population}

According to the 2012 census, Lushoto District is leading in terms of population density compared to the other districts in Tanga region and has a, total of 492441 inhabitants [24].

\subsubsection{Topography}

The topography is highly variable ranging from flat wetlands with gentle slopes to very steep sloping mountainous areas, in places intersected at their base by narrow and moderately wide flat valley bottoms [43]. The altitude varies between 1550 and 2500 meter above sea level (Figure 2). Lushoto District comprises four agro-ecological zones, a dry warm zone, a humid cold zone, a dry cold zone and a dry warm zone, [44]. The study area is located in the humid cold zone. 


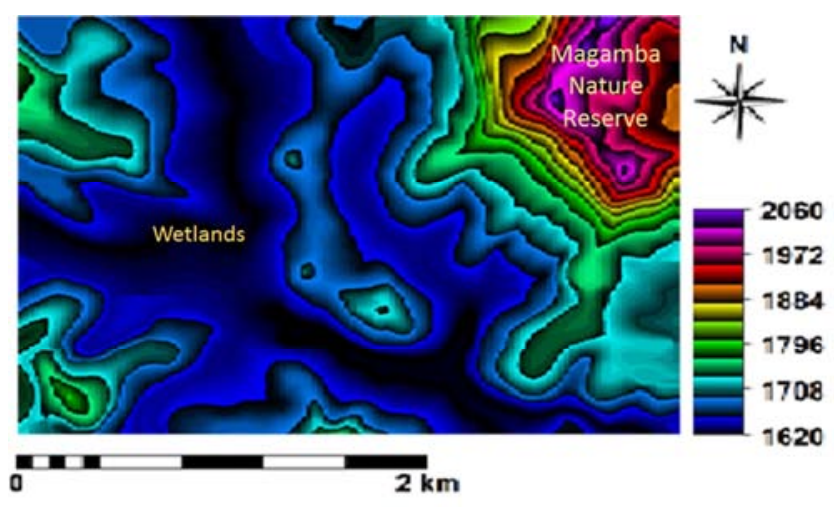

Figure 2. Digital Elevation Model (DEM) and its derivatives showing the topography and drainage pattern of the site.

\subsubsection{Vegetation and Land Use}

The area is covered by both natural and anthropogenic vegetation cover. The main vegetation types in the West Usambara Mountains are natural and plantation forests. The vegetation of natural forest particularly in the Magamba Nature Reserve is comprised of Comphor (Ocotea usambarensis) with Podo (podocarpus usambarensis and Pordicurpus pensiculi) and an undergrowth of Lansthus cirumilee and other shrubs. Associated species are Parinari excels Pygeum africanum, Ficalhoa laurifolie, Polycas spp. Macaranga kilindscharica, Crysophylum spp. Olea hochstetteri and Cassipourea spp. The major species of plantation forest are Cedar (Juniperus proceria) Cypress (Cupresuus lusstanica), Pinus petula and Pinus radiate [46].

The dominant land uses include subsistence and cash crop agriculture (covering $58 \%$ of the area), orchards and commercial plantations (11\%), indigenous protected forest Reserves (16\%) and pastures (15\%) (Shemdoe, 2002). The main cash crops are vegetables, fruits and irish potatoes, while maize (Zea mays), cassava (Manihot esculenta), beans (Phaseolus lunatus) and potato (Solanum tuberosum) are the main food crops [46]).

\subsection{Data Collection}

\subsubsection{Acquisition of Satellite Data}

Data sources were determined based on the objectives of the study. Landsat satellite images (TM for 1984, 1995 and ETM for 2015) used in this study were obtained from, Unites States Geological Survey (USGS) earth explorer Landsat archives (www.earthexplore.usgs.gov) to cover the extent of the study area in UTM zone 37 South between 168 and 65 path and row numbers respectively. The criteria considered for satellite data acquisition are summarised in Table 1.

Table 1. Criteria that considered for remote sensing data acquisition of the study area.

\begin{tabular}{ll}
\hline Criteria & Description \\
\hline Cloud cover & Less than $10 \%$ \\
Capture day & All image taken in daylight \\
Processing system & Level 1 Product Generation system (LPGS) \\
Spatial resolution & 30 meter \\
Period of the year & Dry season \\
Spectral resolution & Multispectral image with 7 bands \\
\hline
\end{tabular}

\subsubsection{Digital Image Processing}

Satellite images downloaded from Landsat archive comes in compressed format. The WinRAR software was used to unzip the folder. Each satellite image is comprised of seven spectral bands which were merged (Layer stalking) using Quantum GIS (QGIS) to obtain a multispectral satellite image for further processing. The downloaded satellite images are projected north and since Tanzania is found in the southern hemisphere, the images were re-projected to south Hence, the obtained multispectral imageries were rectified to the UTM projection, zone 37 on Clarke 1880 spheroid and Arc 1960 datum.

An area of interest (AOI) was selected based on the criteria that the Magamba Nature Reserve and the landscape of the earmarked villages are included in the analysis of analysis of land use/covers and their associated impacts on provisioning of ecosystem services. This AOI was used to subset the three Landsat imageries; TM for 1984, and 1995 and ETM for 2015 all covering the study areas. The Landsat imageries were processed (classified) to generate land cover types and also analysed to determine changes that have taken place within the study areas between years 1984 and 2015. Digital enhancements and atmospheric correction for all downloaded Landsat images for 1984, 1995 and 2015 were also done in QGIS software.

\subsubsection{Image Classification}

The hybrid method was used for classification processes; where the unsupervised classification tool was used to create isodata and signature files. The files were then imported for final supervised classification process. Six classes were formulated and confirmed through the use of ground-truth data. The classes of interest included natural forest, wetland, grassland, agricultural land, built up areas and plantation forest. The supervised classification was performed to cluster pixels in the satellite images into six classes namely: natural forest, wetland, grassland, agricultural land, built up areas and plantation forest. The maximum likelihood classification was performed to assign each pixel in the image to the class that has the highest probability to obtain the respective land use/cover map for each studied landscape site at a spatial resolution of $30 \mathrm{~m}$ by $30 \mathrm{~m}$ and for each period. Sample data sets created for each land use/cover class was used for categorisation of the spectral classes into general land use/cover classes in IDRIS selva and Semi-Automatic Classification Plugin (SCP) in QGIS software.

\subsubsection{Ground Truthing and Classification Accuracy Assessment Data}

Reference points were collected simultaneously during the social economic survey. A total of 20 reference points were collected from the study sites based on the 2015 image. The 2015 imagery was selected for conducting accuracy assessment because it is the most recent image and close to ground observations. In literature it is sighted that if the overall classification accuracy is greater than $80 \%$ the classification is accepted [30]. In this study, the overall accuracy was greater than $80 \%$ and hence was acceptable. 


\subsubsection{Images Analysis and Change Detection Analysis}

The generated land cover maps for 1984, 1995 and 2015 were analysed following map overlay method. Recording were done following supervised classification, and then areas for each land cover category were calculated for both years. The change detection was done by post classification approach using image interpreter|GIS analysis|matrix tool in QGIS software. The approach identifies quantitative changes by comparing two independent classified images pixel by pixel basis using a change detection matrix [1, 19]. The observed matrix was then processed in an intensity analysis program (Pontius matrix excel sheet). Analysis of transition matrix and quantitative change was done based on the definition adopted from [2]. The persistence is an area (Aii, given in a column for category $\mathrm{i}$, or Ajj, given in a row for category $\mathrm{j}$ in the matrix) which remained under the same land cover category over time, i.e. remain unchanged, which in a standard cross-tabulation matrix, is given in the diagonal.

The gross loss, $\mathrm{Li}$, is the area which experiences losing by category $i$ between initial time and subsequent time, given as a difference between total area $(\Sigma \mathrm{Ai}+)$ and persistence in a column (equation 1). The gross gain is the area which experiences gaining by category $j$ between initial time and subsequent time, given as a difference between total area $(\Sigma \mathrm{A}+\mathrm{j})$ and persistence in a row (equation 2$)$.

$$
\begin{aligned}
\mathrm{Li} & =\Sigma \mathrm{Ai}+-\mathrm{Aii} \\
\mathrm{Gj} & =\Sigma \mathrm{A}+\mathrm{j}-\mathrm{Ajj}
\end{aligned}
$$

Net quantity change is the absolute difference between the gross gain and the gross loss (equation 3 ), and overall change for each category is given as the sum of the gross gain and gross loss (equation 4).

$$
\begin{gathered}
\text { Net quantity change }=\text { Gross gain }- \text { Gross loss } \\
\text { Overall change }=\text { Gross gain }- \text { Gross loss }
\end{gathered}
$$

When a land cover experiences gross gain and gross loss simultaneously, a kind of this change is known as swap location change [9], and is given by equation 5 .

Swap location $=$ overall change - Net quantity change (5)

\subsubsection{Collection of Human Activities Data in Different Land Uses}

The Landsat ETM image of 2015 with a medium to high resolution $(30 \mathrm{~m})$ was used as a base map in the field to locate major land uses, the villages, agricultural fields, plantations and roads surrounding the Magamba Nature Reserve. In this exercise field survey coupled with geographic location using Global Positioning System (GPS) were employed to locate and describe different land uses including farming practices, cropping patterns, grazing activities, settlement characteristics and forests according to FAO guidelines [7]. Alongside land use description, detailed forest related human activities were studied at selected sample villages of Bondeni Cost and Mshelemule using semi structured questionnaires and key informants. In this exercise, random sampling technique was used for selection of respondents from the selected villages. A total of 72 respondents were interviewed to capture data on human activities in Magamba Nature Reserve such as firewood collection, illegal timber harvesting, animal grazing, collection of medicinal trees and collection of building poles. In addition to human activities secondary data on management plans of the MNR was obtained from literature.

\subsection{Data Analysis}

\subsubsection{GIS Analysis}

Land use/cover maps were created using remote-sensing and Geographic information System (GIS) techniques (QGIS software). The different locations of the origins and destinations of human activities were also identified in MNR with respect to proximity of the surrounding villages. These locations were mapped as point map and analysed together with other vector map layers of road network, forest and village boundaries using QGIS. These vector map layers were integrated with land use/cover maps in GIS to establish relationship between land use and human activities.

\subsubsection{Human Activities}

Number of people per activity related to Magamba Nature Reserve and the studied villages of Kosti, Mshelemule and Bondeni were quantified using Statistical Package for Social Sciences (SPSS). Descriptive statistical analysis using frequency counts and percentages was used to explain human activities of communities adjacent to the MNR. Qualitative data were analysed using content and structural functional analytical techniques in which components of verbal discussions from different respondents were broken down into the smallest meaningful units of information, values and attitudes of respondents [47].

\section{Results and Discussion}

\subsection{Land Use/Cover Patterns and Distribution}

The total percentage area covered by each land use/cover class (category) in the interface between Magamba Nature Reserve and community village landscape at each period are presented in Figure 3. The maps showing the patterns of land use/cover category in the interface between Magamba Nature Reserve and community village landscape at each epoch are given in Figure 4 . Over $70 \%$ of area was covered by natural forest in 1984, followed by agricultural land and grassland/wetland. In a study conducted by [20] in Pugu Forest Reserve in Dar Es Salaam, Tanzania reported that in 1984 the forest reserve covered $74.6 \%$ when compared to the other land use/covers. This was attributed to minimal human pressure and overexploitation of natural resources. However, over a period of 31 years (1984 - 2015) natural forest covering the major part of Magamba Nature Reserve decreased by 14\% (Figures 3 and 4). Ethiopia - Between 1990 and 2005, the country lost $14 \%$ of its forests [29]. Tanzania is facing unprecedented loss of its forests and other 
woodlands. Between 1990 and 2010 the total loss was estimated to be $19.4 \%$ (about $8,067,000$ ha) of the forest cover [8]. Recent report indicates that the country has already lost about $38 \%$ of its forest cover [32]. According to the report, the rate of loss is 400,000 ha per annum and, the risk is high as the country's entire forests can be depleted within the next 50 to 80 years if the current trend remains unabated. The declining trend for forests in the study area is largely attributed to the increasing agricultural activities, settlements and infrastructure (Figure 3). Given the escalating human population growth (projected to increase from 44.9 million people [31] to 69.1 and 129.1 million in 2025 and 2050, respectively [26], it is apparent that more forests and woodlands will be lost to meet the increased demand for food, agriculture and settlements.

The results presented in Figure 3 shows only the quantity of each category, but doesn't give any details concerning individual transitions and stationarity between categories [1]. Persistence, gross gain and loss for each category are explained in Tables 2 and 3 for the interface between Magamba Nature Reserve and community village landscape. The gross loss column shows the quantity of land cover that experiences a gross loss of land use/cover during 1984-1995 and 1995-2015 time interval, and the gross gain column shows the quantity of land use/cover that experiences a gross gain of land use/cover between the same time intervals [2].

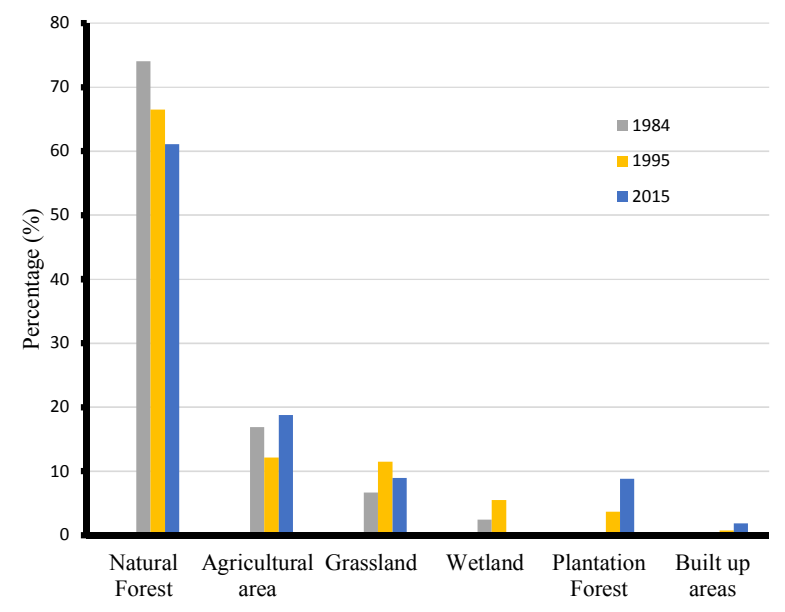

Figure 3. Percentage area covered by land use/cover category in the interface between Magamba Nature Reserve and community village landscape at each epoch.
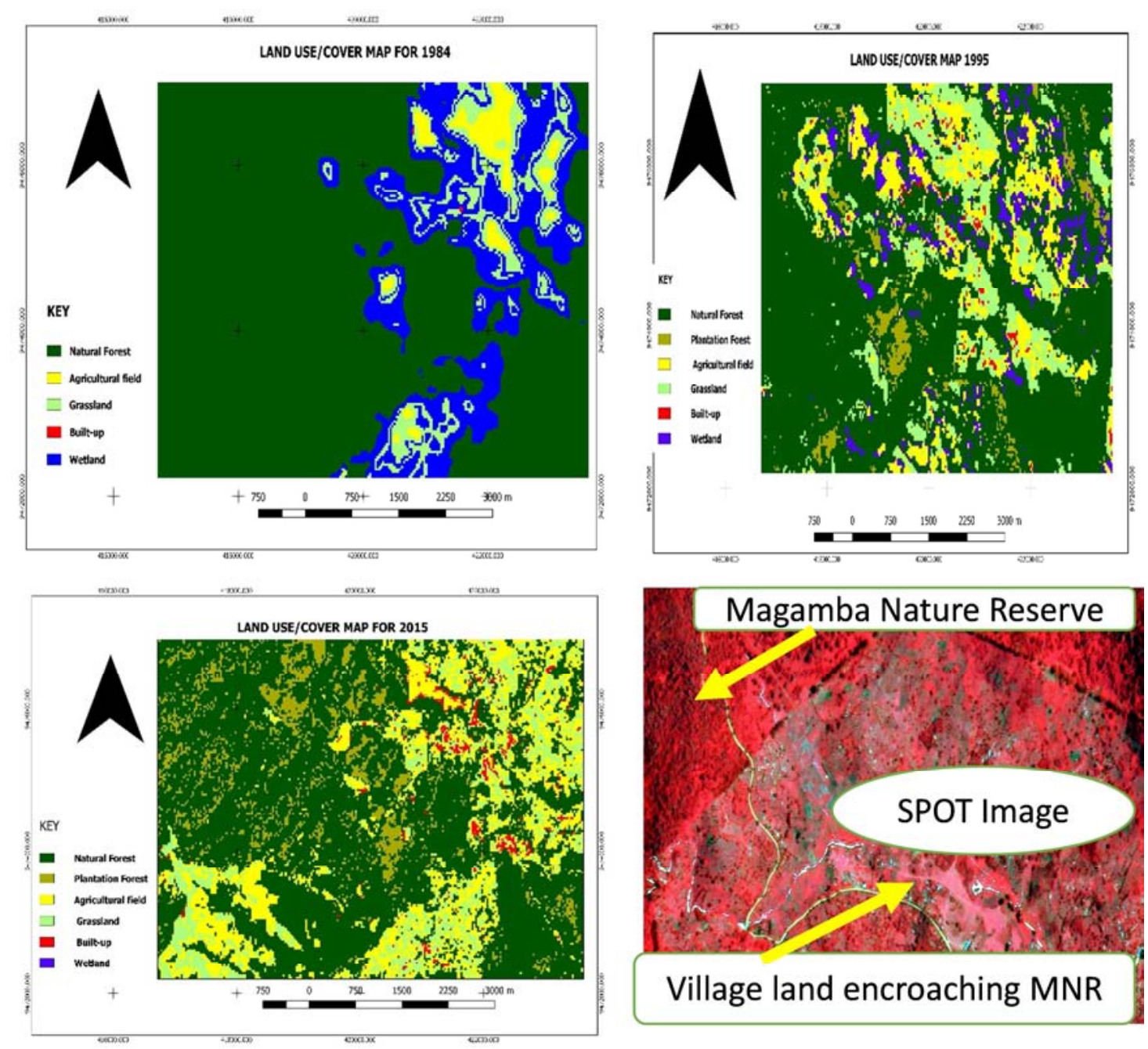

Figure 4. Land use/cover category pattern in the interface between Magamba Nature Reserve and community village landscape at each epoch. 
Table 2 shows that the largest gross loss in 1984-1995 was experienced by natural forest ( $725.3 \mathrm{ha})$, followed by wetland (513.4 ha) and grassland (196.7 ha), while net quantity change shows that natural forest and wetlands are losing with 250.9 ha and 376.9 ha respectively (Table 4). In 1995-2015, the largest gross loss was observed for natural forest $(842.5$ ha) followed by grassland ( $355.7 \mathrm{ha}$ ) and agricultural land (329.6 ha) while wetlands were (181.6 ha) (Table 3 ). In this period the net quantity change shows that natural forests are losing 178.7 ha and wetlands 165.0 ha while grassland 84.9 ha (Table 4).

Table 2. Cross tabulation matrix showing observed persistence (on the main diagonal) and observed land cover changes (off the main diagonal) for 1984-1995 time interval in the interface between Magamba Nature Reserve and community village landscape.

\begin{tabular}{|c|c|c|c|c|c|c|c|c|c|}
\hline & \multicolumn{9}{|l|}{1995} \\
\hline & Class name & NF & PF & $\mathbf{A L}$ & GL & BU & WL & Total 1995 & Gross Loss \\
\hline \multirow{8}{*}{1984} & $\mathrm{NF}$ & 1733.4 & 92.6 & 250.7 & 261.6 & 18.5 & 101.9 & 2458.7 & 725.3 \\
\hline & $\mathrm{PF}$ & 0.0 & 0.0 & 0.0 & 4.0 & 5.0 & 2.0 & 11.0 & 11.0 \\
\hline & $\mathrm{AL}$ & 39.3 & 3.0 & 16.0 & 13.2 & 0.0 & 8.6 & 80.2 & 64.2 \\
\hline & GL & 124.3 & 10.5 & 36.5 & 23.7 & 1.5 & 23.9 & 220.4 & 196.7 \\
\hline & $\mathrm{BU}$ & 0.2 & 0.0 & 0.4 & 0.2 & 0.0 & 0.1 & 0.8 & 0.8 \\
\hline & WL & 310.7 & 16.8 & 99.3 & 82.4 & 4.2 & 47.3 & 560.6 & 513.4 \\
\hline & Total 1984 & 2207.9 & 122.9 & 402.9 & 385.1 & 29.2 & 183.7 & 3331.8 & 1511.4 \\
\hline & Gross Gain & 474.5 & 122.9 & 386.9 & 361.4 & 29.2 & 136.5 & 1511.4 & \\
\hline
\end{tabular}

$\mathrm{NF}=$ Natural forest, $\mathrm{PF}=$ Plantation forest, $\mathrm{AL}=$ Agricultural land, $\mathrm{GL}=$ Grassland, $\mathrm{BU}$ Built up areas, $\mathrm{WL}=\mathrm{Wetlands}$.

Table 3. Cross tabulation matrix showing observed persistence (on the main diagonal) and observed land cover changes (off the main diagonal) for 1995-2015 time interval in the interface between Magamba Nature Reserve and community village landscape.

\begin{tabular}{|c|c|c|c|c|c|c|c|c|c|}
\hline & \multicolumn{9}{|l|}{2015} \\
\hline & Class name & NF & PF & $\mathbf{A L}$ & GL & BU & WL & Total 2015 & Gross Loss \\
\hline \multirow{7}{*}{1995} & $\mathrm{NF}$ & 1365.4 & 187.5 & 404.7 & 204.5 & 38.7 & 7.0 & 2207.9 & 842.5 \\
\hline & $\mathrm{PF}$ & 74.4 & 4.4 & 27.5 & 15.3 & 1.4 & 0.0 & 122.9 & 118.6 \\
\hline & $\mathrm{AL}$ & 242.4 & 47.5 & 74.2 & 29.9 & 8.9 & 0.9 & 403.7 & 329.6 \\
\hline & GL & 234.1 & 36.1 & 69.5 & 25.4 & 7.3 & 8.8 & 381.1 & 355.7 \\
\hline & BU & 15.8 & 2.5 & 3.9 & 1.7 & 0.3 & 0.0 & 24.2 & 23.9 \\
\hline & Total 1995 & 2029.2 & 293.9 & 623.6 & 296.2 & 62.0 & 17.5 & 3322.4 & 1851.9 \\
\hline & Gross Gain & 663.8 & 289.5 & 549.4 & 270.8 & 61.6 & 16.6 & 1851.9 & \\
\hline
\end{tabular}

$\mathrm{NF}=$ Natural forest, $\mathrm{PF}=$ Plantation forest, $\mathrm{AL}=$ Agricultural land, $\mathrm{GL}=$ Grassland, $\mathrm{BU}$ Built up areas, $\mathrm{WL}=\mathrm{Wetlands}$.

Table 4. Quantitative land use/cover change observed for the period interval 1984-1995 and 1995-2015 in the interface between Magamba Nature Reserve and community village landscape.

\begin{tabular}{|c|c|c|c|c|c|c|c|}
\hline Years & Land use/cover classes & $\begin{array}{l}\text { Gross } \\
\text { Gain }\end{array}$ & $\begin{array}{l}\text { Gross } \\
\text { Loss }\end{array}$ & Sum & $\begin{array}{l}\text { Net Quantity } \\
\text { Change }\end{array}$ & $\begin{array}{l}\text { Absolute Net Quantity } \\
\text { Change }\end{array}$ & Swap Location \\
\hline \multirow{6}{*}{$\begin{array}{l}1984- \\
1995\end{array}$} & $\mathrm{NF}$ & 474.5 & 725.3 & 1199.8 & -250.9 & 250.9 & 1450.7 \\
\hline & $\mathrm{PF}$ & 122.9 & 11.0 & 133.9 & 111.9 & 111.9 & 22.0 \\
\hline & $\mathrm{AL}$ & 386.9 & 64.2 & 451.1 & 322.7 & 322.7 & 128.3 \\
\hline & GL & 361.4 & 196.7 & 558.1 & 164.6 & 164.6 & 393.5 \\
\hline & $\mathrm{BU}$ & 29.2 & 0.8 & 30.0 & 28.4 & 28.4 & 1.6 \\
\hline & WL & 136.5 & 513.4 & 649.8 & -376.9 & 376.9 & 1026.7 \\
\hline \multirow{5}{*}{$\begin{array}{l}1995- \\
2015\end{array}$} & $\mathrm{PF}$ & 289.5 & 118.6 & 408.1 & 171.0 & 171.0 & 237.2 \\
\hline & $\mathrm{AL}$ & 549.4 & 329.6 & 879.0 & 219.9 & 219.9 & 659.2 \\
\hline & GL & 270.8 & 355.7 & 626.5 & -84.9 & 84.9 & 711.4 \\
\hline & $\mathrm{BU}$ & 61.6 & 23.9 & 85.5 & 37.7 & 37.7 & 47.8 \\
\hline & WL & 16.6 & 181.6 & 198.3 & -165.0 & 165.0 & 363.2 \\
\hline
\end{tabular}

$\mathrm{NF}=$ Natural forest, $\mathrm{PF}=$ Plantation forest, $\mathrm{AL}=$ Agricultural land, GL $=$ Grassland, $\mathrm{BU}$ Built up areas, $\mathrm{WL}=\mathrm{Wet}$ lands.

Category intensity analysis for the period interval 19841995 and 1995-2015 are given in Figures 5 and 6 respectively. Results show dormant and active land use/cover change intensity for all categories during 1984-1995 (Figure 5). The results reveal that natural forest area and wetlands had active intensity of gain (with intensity beyond uniform intensity), but the intensity of the former was more active than that of the latter (Figure 5). In other land use/covers, the intensity of loss was relatively active. Active intensity of loss are both apparent for built up area, grassland and plantation forest (Figure 5). Active intensity of gain for natural forest area can be attributed to low population pressure during time interval. Figure 6 shows dormant and active land use/cover change intensity for all categories during 1995-2015. 


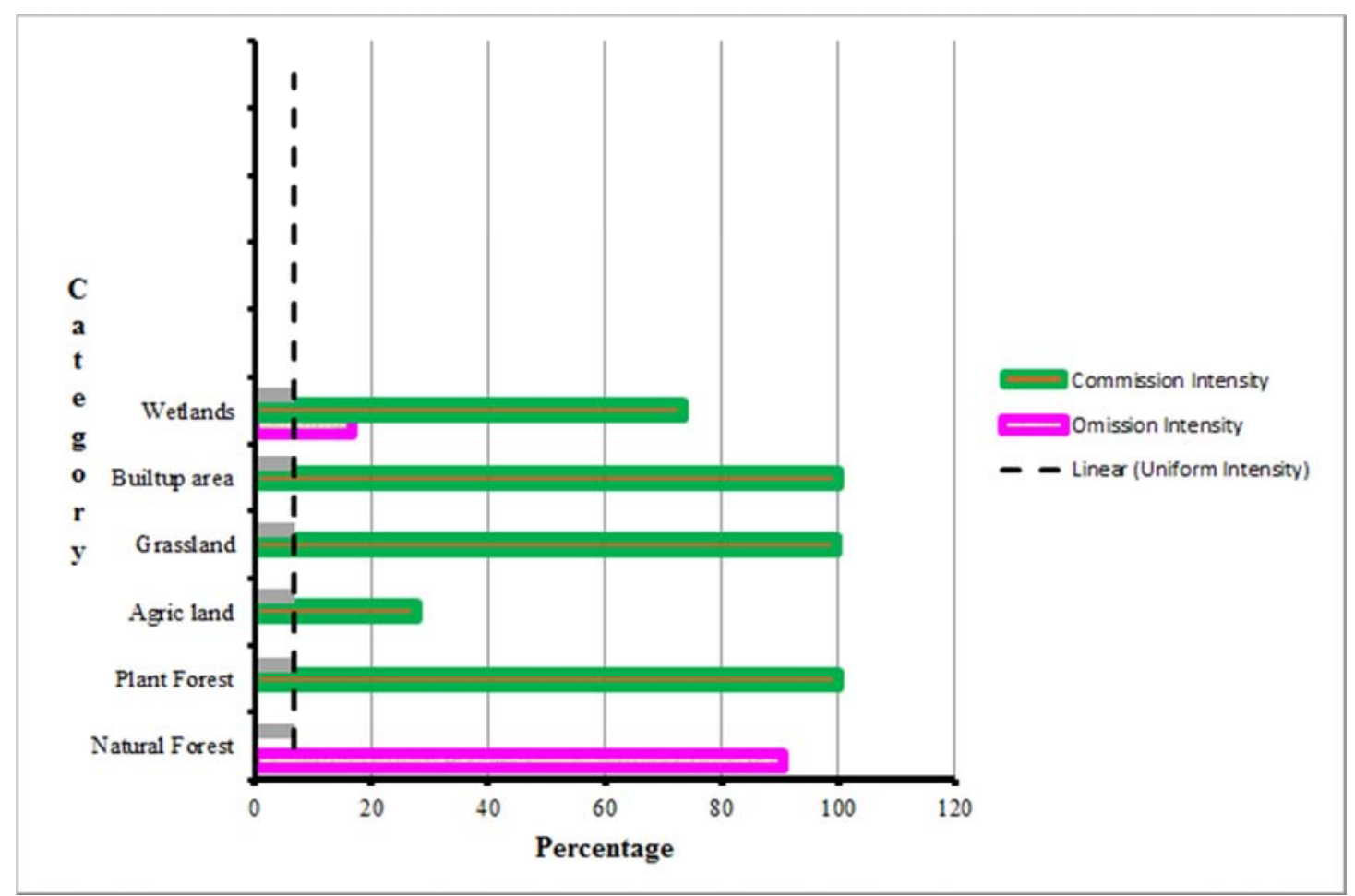

Figure 5. Category intensity analysis for the period interval 1984-1995.

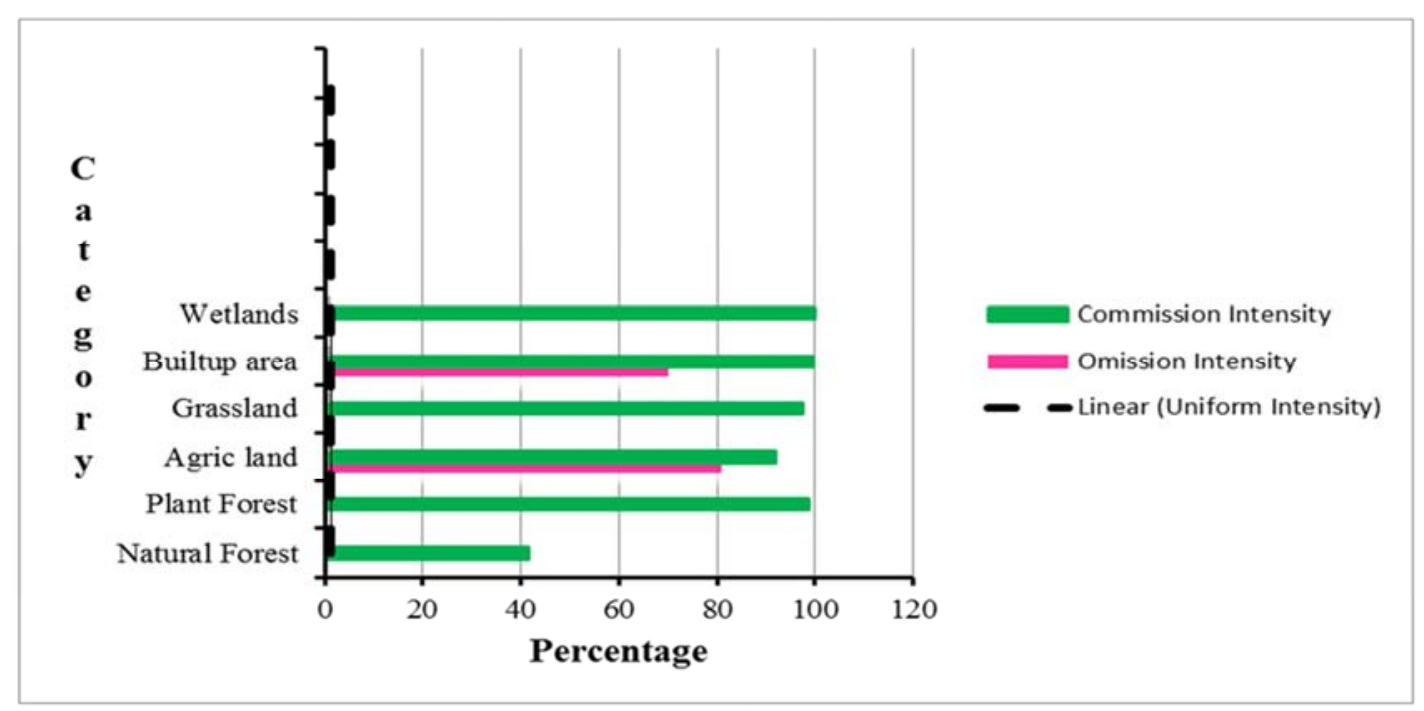

Figure 6. Category intensity analysis for the period interval 1995-2015.

The results reveal that natural forest, wetlands, grassland and plantation forest areas had active intensity of loss (with intensity beyond uniform intensity), while agricultural land and built up areas had active intensity of gain (with intensity beyond uniform intensity) (Figure 6).

The expanding agricultural land and built up areas is attributed to increased population pressure and the need to meet livelihood demands which have impacted negatively on the forest ecosystem services. In a study conducted in Mweka and Lyasomboro villages in Moshi rural district to examine changes in resource use patterns and ultimately forest cover and biodiversity in half mile forest strip of Mount Kilimanjaro,
William (2003) reported the presence of maximum anthropogenic pressure such as encroachment and expansion of agriculture into the forest resulted in increased demand of forest ecosystem products and land to meet livelihood demands. In Lake Naivasha drainage basin, Kenya, Kenned (2008) observed the increase in agricultural land as a result of introduced horticulture production for the commercial purposes which lead to the deterioration of forest cover.

\subsection{Effect of Human Activities on Land Use/Cover Change in the Magamba Nature Reserve Interface}

The results present various human activities among the 
interviewed households in the in the interface between Magamba Nature Reserve and community village landscape. The most common human activities related to utilisation of forest products are firewood collection for household use, collection of medicinal plants, illegal timber harvesting, animal grazing, cutting trees for building poles and Charcoal burning. The intensity for these activities on the studied villages of Bondeni, Cost, and Mshelemule differ from village to village as presented in Table 5. Firewood collection is the most important human activity associated with forest degradation in Magamba Nature Reserve. Although firewood collection is prohibited in the Nature Reserve and people are aware of the rules and regulations, but still a number of them are engaged in the activity. This could be explained by various factors including increasing demand for firewood due rapid population growth and lack of alternative sources of energy in most rural areas [4]. According to [9] firewood collection in Nature Reserves could result in serious ecological destruction including, removal of dead wood, which provides food and shelter to a wide range of animal and fungal species hence loss of biodiversity. Collection of medicinal plants is associated with forest degradation as the process is destructive in the sense that it involves uprooting plants, root cutting, and tree ring debarking [9].

Table 5. Most common human activities from the surrounding villages impacting the Magamba Nature Reserve.

\begin{tabular}{llll}
\hline Human Activities & Bondeni\% & $\begin{array}{l}\text { Villages } \\
\text { Cost\% }\end{array}$ & Mshelemule\% \\
\hline Firewood collection & 28 & 33 & 31 \\
Medicinal plants & 24 & 21 & 20 \\
Illegal timber harvesting & 13 & 12 & 7 \\
Animal grazing & 11 & 13 & 7 \\
Building poles & 3 & 4 & 8 \\
Charcoal burning & 1 & 0 & 1 \\
Agriculture Activities & 12 & 9 & 4 \\
Business & 6 & 5 & 14 \\
Employment & 2 & 3 & 8 \\
\hline
\end{tabular}

Illegal timber harvesting in MNR by communities around the Nature Reserve is a lucrative business providing income and employment opportunities in the area. High demands of timber in domestic and cross-border markets pose significant threat to sustainable management of forests in the MNR [21]. These demands enhance destruction of forest resources, biodiversity and forest services such as water and climate [28]. Low cost housing in and around the study area is sustained mainly by building poles harvested from forest and forest reserves including MNR. Field observations show that long and straight building poles and of good diameter are commonly harvested for house construction in the villages surrounding Magamba Nature Reserve. This activity is associated with destruction of the existing tree species and also retards plant regeneration process. Animal grazing and charcoal burning are other human activities taking place in Magamba Nature Reserve. Grazing in forest reserves destroys young tree seedlings and impairing natural regeneration of trees [10]. The growing population of Lushoto town and other rural market centres is likely to increase the demand for charcoal as a major source of energy for households [5]. According to [24], population size of Lushoto District for the year 2002 was 419970 and 492441 for the year 2012 which is an increase of $17 \%$ over a period of 10 years. Population size and density are reported to have major consequences for the intensity of forest resource use [7] including extraction of forest products and services [23].

\section{Conclusions and Recommendations}

i. The study has identified the spatial and temporal dynamics on land use/land cover in Magamba Nature Reserve interface in Lushoto district, Tanzania. The results demonstrated that the study area had undergone numerous changes in land use/land cover over a period of 31 consecutive years (1984 - 2015). Over the period natural forest covering the major part of Magamba Nature Reserve decreased by $14 \%$. The declining trend for forests in the study area is largely attributed to the increasing agricultural activities, settlements and infrastructure. These changes not only indicate the loss of natural vegetation for the present generation but also indicate that the future generation is being jeopardized and more critical if the condition won't be arrested.

ii. Intensity of land use/cover changes in terms of gains and losses varied across categories for each time interval. The gains and losses were apparent through development of new land uses such as opening up new land for agriculture, built up areas and encroachment of forest resources or complete transformation of land uses/cover. The results revealed that natural forest area and wetlands had active intensity of gain over the period 1984-1995 while in the $1995-2015$ period had active intensity of loss.

iii. The most common human activities related to the spatial and temporal dynamics of land use/land cover in the Magamba Nature Reserve were firewood collection for household use, collection of medicinal plants, illegal timber harvesting, animal grazing, cutting trees for building poles and Charcoal burning.

iv. Firewood collection is the most important human activity associated with forest degradation in Magamba Nature Reserve despite the fact that the activity is prohibited in the Nature Reserve and people are aware of the rules and regulations, but still a number of them are actively engaged in the activity.

v. Results revealed that collection of medicinal plants from Magamba Nature Reserve is associated with forest degradation as the process is destructive in the sense that it involves uprooting plants, root cutting, and tree ring debarking.

vi. Illegal timber harvesting in MNR by communities around the Magmaba Nature Reserve is a lucrative business providing income and employment opportunities in the area. High demands of timber in domestic and cross-border markets pose significant 
threat to sustainable management of forests in the MNR.

vii. In order to reduce dependence of the forests for firewood and charcoal by the local communities it is vital for the policy makers as well as nongovernmental organizations to identify and establish potential low cost alternative sources of energy for usage by rural domestic households

viii. Future efforts to predict and map spatial and temporal land use/cover dynamics at landscape scale should consider future scenarios on the evolution of forestrural landscape interfaces and their impact on the provisioning of ecosystem services (ESS)

ix. The potential of remote sensing data including Sentinel satellite data for quantitative evaluation of biophysical variables in the forest- rural landscape interface should be explored

\section{Acknowledgements}

This work was supported by the Department of Ecotourism and Nature conservation of Sebastian Kolowa Memorial University, Lushoto, Tanzania. The authors greatly appreciate the cooperation of many people including communities in the study area who in many ways facilitated the accomplishment of this work. Prof Didas Kimaro of Mwenge Catholic University (MWECAU), Moshi, Tanzania is highly acknowledged for his scientific mentoring and motivation and technical guidance and constructive comments which enabled smooth completion of this work.

\section{References}

[1] Aldwaik S. and Pontius J. R. G. (2012). Intensity analysis to unify measurements of size and stationarity of land changes by interval, category, and transition, Landscape and Urban Planning, vol. 106: 103-114.

[2] Alo C. and Pontius J. R. G. (2008). Identifying systematic land cover transitions using remote sensing and GIS: The fate of forests inside and outside protected areas of Southwestern Ghana, Environment and Planning B., vol. 25: 280-295.

[3] Burgess, N. D., Butynski T. M., Cordeiro N. J., Doggart N. H., Fjeldsa J., Howell K. M., Kilahama F. B., Loader S. P., Lovett J. C., Mbilinyi B., Menegon M., Moyer D. C., Nashanda E., Perkin A., Rovero F., Stanley W. T. and Stuart S. N. (2007). The biological importance of the Eastern Arc Mountains of Tanzania and Kenya. Biological Conservation 134: 209-231.

[4] Campbell, B. (1996). The miombo in transactions woodland and welfare in Africa. Centre of international forest research. Bogae, Malysia. ISBN 979-8764-07-2. 67pp.

[5] Clark, G. P. and Dickinson, A. (1995). Status report for 11 coastal Forest in Coastal region, Tanzania. Frontier Tanzania Technical Report No. 17 the society for environmental Exploration and the University of Dar es Salaam. 77pp.

[6] Cuni-Sanchez A, White LJT, Calders K, Jeffery KJ, Abernethy K, Burt A, et al. (2016) African Savanna-Forest Boundary Dynamics: A 20-Year Study. PLoS ONE 11 (6): e0156934. doi: 10.1371/journal.pone.0156934.
[7] FAO (2003). Forestry Outlook Study for Africa. Regional report- opportunities and challenges towards 2020. Forestry Paper 141, Italy: FAO. 12pp.

[8] FAO (2010). Global Forest Resources Assessment 2010, Main Report, FAO Forestry Paper 163. Food and Agriculture Organization of the United Nations, Rome.

[9] FBD (2006). Strategies for sustainable forest uses in Eastern Arc Mountains, Tanzania The Conservation and Management of the Eastern Arc Mountain Forests Project, Forest and Beekeeping Division Ministry of Natural Resources and Tourism Tanzania GEF/UNDP: URT/01/G3. pp. 2-8.

[10] Holtmeir, F. K. (2012). Impact of wild herbivorous mammals and birds on the altitudinal and northern treeline ecotones. Journal of international Association for Landscape ecology 30: 1-28.

[11] Kihupi, M. L., Chingonikaya, E. E., \& Mahonge, C. (2015). Smallholder farmers' perception of climate change versus meteorological data in semi-arid areas of iringa district, tanzania. Journal of Environment and Earth Science, 5.

[12] Kihupi, N. I., Tarimo, A. K., \& Dihenga, H. O. (2007). Spatial and temporal variation of growing season characteristics in Tanzania. Journal of the Geographical Association of Tanzania, 32, 33-49.

[13] Kihupi, N. I., Tarimo, A. K., Masika, R. J., Boman, B., \& Dick, W. A. (2015). Trend of growing season characteristics of semi-arid arusha district in tanzania. Journal of Agricultural Science, Vol. 7.

[14] Kingamkono, R. M. L, Kihupi, N. I, \& Dihenga, H. O. (1994). Length of growing season vis-a-vis rainfall distribution in Tanzania. Proceedings of the 5th Annual Scientific Conference of SADC-Land \& Water Management Research Programme (pp. 141-155). Harare, Zimbabwe: SADC-L\&WMRP.

[15] Loveland, T., Mahmood, R., Weynand, P. T., \& karstensen, K. (2012). National climate assessment technical report on the impacts of climate and land use and land cover change. USA: U.S. Department of the interior and U.S. Geological Survey.

[16] Mahmood, R., Pielke, R. A., Hubbard, K. G., Niyogi, D., \& Bonan, G. (2010). impacts of land use/land cover change on climate and future research priorities. Papers in Natural Resources, Paper 395.

[17] Majule, A. E., Janie, R., Mathew, M., \& Kaisa, K. (2014). Review of climate change mitigation in agriculture in Tanzania. Tanzania: MICCA Programme, FAO.

[18] Mary, A. L., \& Majule, A. E. (2009). Impacts of climate change, variability and adaptation strategies on agriculture in semi arid areas of TanzaniaThe case of Manyoni District in Singida Region, Tanzania. African Journal of Environmental Science and Technology, Vol. 3 (8), pp 206-218.

[19] Mbilinyi B. P. (2000). Assessment of land degradation and its consequences: Use of remote sensing and geographical Information system techniques: A case study in the ismani division, Iringa region, Tanzania. $\mathrm{PhD}$ Thesis, Berlin, Technical University. Pp 139.

[20] Mdemu, M., Kashaigili, J. J., Lupala, J., Levira, P., Liwenga, E., Nduganda, A., \& Mwakapuja, F. (2012). Dynamics of land use and land cover changes in the Pugu and Kazimzumbwi Forest Reserves. Proceedings of the first Climate Change Impacts, Mitigation and Adaptation Programme Scientific Conference, 2012. Ardhi University. 
[21] Milledge, S. A. H. and Elibariki, R. (2005). The status of logging in southern Tanzania. Unpublished technical report submitted to the WWF East Africa Coastal Forests Ecoregion Programme. Dar es Salaam.

[22] Mitchard ETA, Flintrop CM. (2013) Woody encroachment and forest degradation in sub-Saharan Africa's woodlands and savannas 1982-2006. Philosophical Transactions Royal Society B368: 20120406. http://dx.doi.org/10.1098/rstb.2012.0406

[23] Mitinje, E., Kessy, J. F. and Mombo, F. (2007). SocioEconomic Factors Influencing Deforestation on the Uluguru Mountains, Morogoro, Tanzania. DiscovInnov 19: 146-147.

[24] National Bureau of Statistics (NBS) (2013). 2012 Population and housing census. The United Republic of Tanzania. Dar es Salaam: Government Printer. pp. 45-47.

[25] Pontius R. G. J., Shusas E. and McEachern M. (2004). Detecting important categorical land changes while accounting for persistence," Agriculture, Ecosystems and Environment, vol. 101: 251-268.

[26] PRB (Population Reference Bureau) (2013). 2013 World Population Sheet. Washington, DC; www.prb.org

[27] Sanga, G. J., Moshi, A. B., \& Hella, J. P. (2013). Small Scale Farmers' Adaptation to Climate Change Effects in Pangani River Basin and Pemba: Challenges and Opportunities. International Journal of Modern Social Sciences, 169-194.

[28] Tacconi, L. (2007). Illegal logging: Law enforcement, livelihoods and the timber trade. London: Earth scan. 45 pp.

[29] Tadesse D. (2007). Forest cover change and socio-economic drivers in SW Ethiopia. MSc Thesis. Technical University Munich, Center of Land Management and Land Tenure, Germany.

[30] Turan S. O., Kodiogullari A. I. and Gunlu A. (2010). Spatial and temporal dynamics of land use pattern response to urbanization in Kastamonu, African journal of Biotechnology, vol. 9: 640-647.

[31] URT (2012). National Strategy for Reduced Emissions from Deforestation and Forest Degradation (REDD+). Division of Environment, Office of the Vice-President, Dar es Salaam, Tanzania.

[32] URT (2014). Fifth National Report on the Implementation of the Convention on Biological Diversity. Vice President's Office, Division of Environment, Dar es Salaam Tanzania.

[33] WFP (2006): United Republic of Tanzania: Comprehensive Food Security \& Vulnerability Analysis (CFSVA). (Conducted in December 2005/January 2006). United Nations World Food Programme, Rome Italy.

[34] WFP (2008): United Republic of Tanzania: Comprehensive Food Security \& Vulnerability Analysis (CFSVA). (Conducted in December 2007/January 2008). United Nations World Food Programme, Rome Italy.

[35] Willcock S., Phillips O. L, Platts P. J., Balmford A., Burgess N. D., Lovett J. C., Ahrends A., Bayliss J., Doggart N., Doody K., Fanning E, Green J. M. H., Hall J., Howell K. L., Marchant R., Marshall A. R., Mbilinyi B., Munishi P. K. T., Owen N., Swetnam R. D., Topp-Jorgensen E. J. and Lewis S. L. (2014). Quantifying and understanding carbon storage and sequestration within the Eastern Arc Mountains of Tanzania, a tropical biodiversity hotspot. Carbon Balance and Management, http://www.cbmjournal.com/content/9/1/2

[36] Winowiecki L., Vågen T., Huising J. (2016). Effects of land cover on ecosystem services in Tanzania: A spatial assessment of soil organic carbon, Geoderma 263: 274-283.

[37] Lyimo, J.G., and Kangalawe, R.Y.M. (2010). "Vulnerability and Adaptive Strategies to the Impact of Climate Change and Variability. The Case of Rural Households in Semi-Arid Tanzania.” Environmental Economics 1, no. 2: 89-97.

[38] Swai, E.Y. and Majule, A. E. (2009). "Drought as the Main Challenge for Crop Production in Semi-Arid Areas: Introduction of Conservation Tillage under Rain-fed Agriculture in Central Tanzania." In Regional Conference on Strengthening Local Agricultural Innovations to Adapt to Climate Change in Botswana, Malawi, South Africa and Tanzania. Dar es Salaam, Tanzania 24-26 August 2009 edited by: P.S. Maro and A.E. Majule. Institute of Resource Assessment (IRA), University of Dar es Salaam, Tanzania.

[39] Mongi, H., Majule A.E. and Lyimo, J.G. (2009). "Vulnerability and Adaptation of Rain Fed Agriculture to Climate Change and Variability in Semi-Arid Tanzania." African Journal of Environmental Science and Technology 4, no. 6 : 371-381.

[40] Yanda, P. E.K. Shirima, F.N. Madulu, A.S. Kauzeni, (2001). Survey and Mapping of Land Use/Cover and Erosion Hazard in Lake Victoria Basin. A Report to LVEMP, Dar es Salaam, Tanzania.

[41] James Halperin and T. Shear, (2005). An Assessment of Rainforest Distribution and Threats in the West Usambara Mountains, Tanzania; Geocarto International 20 (1): 51-61 DOI: $10.1080 / 10106040508542336$.

[42] Conte CA. 1999. The forest becomes desert: Forest use and environmental change in Tanzania'sWest Usambara Mountains. Land Deg Dev. 10: 291-309.

[43] Neerinckx S, Peterson A, Gulinck H, Deckers J, Kimaro D, Leirs H. Predicting Potential Risk Areas of Human Plague for the Western Usambara Mountains, Lushoto District, Tanzania. The American Journal of Tropical Medicine and Hygiene. 2010; 82 (3): 492-500. doi: 10.4269/ajtmh.2010.09-0426.

[44] Annekatrien Debien, Simon Neerinckx, Didas Kimaro, Hubert Gulinck (2010). Influence of satellite-derived rainfall patterns on plague occurrence in northeast Tanzania; Int $\mathrm{J}$ Health Geogr. 2010; 9: 60. doi: 10.1186/1476-072X-9-60.

[45] International Institute for Applied Systems Analysis: Local knowledge on ecosystem management practices and human plague problems in west Usambaras, Tanzania: interim report Laxenburg, Austria; 200.

[46] Kamugisha, M.L., Gesase, S., Minja, D., Mgema, S., Mlwilo, T.D., Mayala, B.K., Msigwa, S., Massaga, J.J. \& Lemnge, M.M. (2007) Pattern and spatial distribution of plague inLushoto, north-eastern Tanzania. Tanzania Health Research Bulletin 9, 12-18.

[47] Kajembe, G. C., (1994), Indigenous Management system as a basis for community forestry in Tanzania: A case study for Dodoma Urban and Lushoto Districts. Tropical Resource Management Paper No. 6, Wageningen Agricultural University, Wageningen. 194pp. 